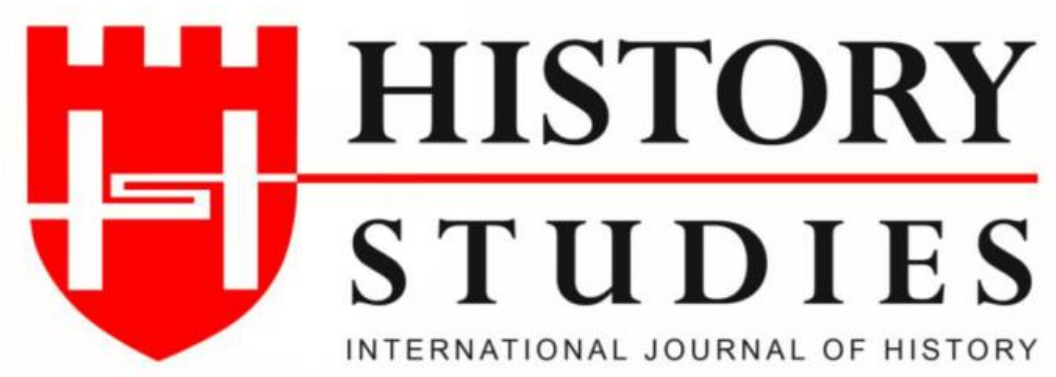

ISSN: 13094173 (Online) 1309 - 4688 (Print)

Volume 12 Issue 6, December 2020

DOI Number: 10.9737/hist.2020.958

Araştırma Makalesi

Makalenin Geliş Tarihi: 15.09.2020 Kabul Tarihi: 16.10.2020

Atıf Künyesi: Hürü Sağlam Tekir, “Osmanlıda Kimsesiz ve Yoksul Çocuklara Anne Şefkati: Irzahane", History Studies, 12/6, Aralık 2020, s. 3127-3146.

\title{
Osmanlıda Kimsesiz ve Yoksul Çocuklara Anne Şefkati: Irzahane
}

Irzahane: Motherly Affection for Orphaned and Poor Children in The Ottoman Empire

\author{
Dr. Hürü Sağlam Tekir \\ ORCID No: 0000-0002-5351-0384 \\ Sinop Üniversitesi
}

Öz

19. yüzyıl boyunca Osmanlı Devleti, modernleşmenin de etkisiyle sosyal hayatın birçok alanında etkisini artırmıştır. II. Abdülhamid döneminin siyasi söyleminde, fakir ve muhtaç halkın özellikle çocukların korunması hep var olmuştur. Padişah'ın kuruluşuna vesile olduğu sosyal yardım kurumları bu dönemde yaşayan yoksullar için hayata daha sıkı tutunma ya da hayatta kalma anlamında bir şans oluşturmuştur. Bu kurumlardan bir tanesi de Darülaceze içerisinde kimsesiz, yoksul ve yetim çocukların kabul edildiği ırzahanedir.

Irzahaneden bahsetmek aynı zamanda dönemin kimsesiz ve yoksul çocuklarının profilini de ortaya koymak anlamına gelir. Öte yandan devletin bu çocuklara yaklaşımı ve bakış açısı ele alındığında çocuk bakımını, modernleşmenin ve sosyalleşmenin neresine koyduğunu da kanıtlayacaktır. Bu anlamda çalışmada; ırzahanenin işleyişinin ne şekilde olduğu, hangi çocukların bu kuruma alındığı, çocuk bakımının ve beslenmesinin incelikleri, çocuk nüfusunun sayısal verilerle değerlendirilmesi ve çocuklara yaklaşımın hassasiyetleri dönemin genel şartları da göz önüne alınarak açıklanmaya çalışılmıştır. Nitekim bu çalışma ile yukarıda bahsedilen bakış açısı ve tarihsel sürece uygun olarak Osmanlıda çocukluğun modern inşası bağlamında 1rzahanenin kuruluş serüveni ve buradaki düzen anlatılmıştır. Çalışmada ırzahane konusu arşiv belgeleri temel alınarak, gazete, dergi ve resmi yayınlar 1şı̆̆ında hazırlanmıştır.

Anahtar Kelimeler: Osmanlı, Çocuk, Irzahane, Darülırza, Darülaceze, Süt.

\section{Abstract}

Throughout the $19^{\text {th }}$ century, the Ottoman Empire increased its influence in many areas of social life with the effect of modernisation, among others. The protection of the poor and needy people, especially children, was always a part of the political discourse of the era of Abdul Hamid II. The social welfare institutions that were established thanks to the Sultan created an opportunity for the poor living in this era to hold on to life more effectively or, 
at least, survive. Irzahane, which were a part of Darülacezes and admitted orphaned and poor children, were one of those institutions.

An analysis of 1rzahane also means revealing the profile of the orphaned and poor children of the time. Discussing the State's approach to, and perspective on, these children will also show how the State positioned childcare in terms of modernisation and socialisation. In this context and in consideration of the general conditions of the era, the present study tried to explain the functioning of irzahanes, the conditions of admittance to this institution, the subtleties of childcare and nutrition, the demographics of child population and the sensitivity in the approach to children. In the context of the construction of modern childhood in the Ottoman Empire, the study described the story of the establishment of rrzahanes and their order in accordance with the above-mentioned perspective and historical process. The topic of irzahane drew upon archival documents, including newspapers, magazines and official publications.

Keywords: Ottoman, Child, Irzahane, Darülırza, Darülaceze, Milk.

\section{Giriş}

Çocukla doğrudan ya da dolaylı olarak ilgili olduğu görülen ya da varsayılan her türlü bilgi, belge, nesne çocukluğun tarihini yazmada katkı sağlamaktadır. Osmanlı haremi, Osmanlı şenlikleri, Enderun Mektebi, çocukla doğrudan ilgili devlet kurumlarının, toplumsal kurumların incelenmesi de çocuk tarihi araştırmalarında kaçınılmazdır. Çocukla en yakından ilgili toplumsal olgu eğitim olduğu için eğitim tarihi çocukluğun tarihiyle de doğrudan ilişkilidir. ${ }^{1}$ Nitekim Osmanlı toplumunda aile, kadın ve toplumsal cinsiyet üzerine yapılan çalışmalar çocukların yaşamlarına dair önemli ipuçları sağlamıştır. Çalışmaların büyük bir çoğunluğu mahkeme kayıtları ve fetva mecmualarına dayanılarak yapılmış; Osmanlı ailesinin büyüklüğü, çocuk evlilikleri, çocukların din değiştirmeleri gibi konulardaki bilgi birikimine önemli katkılar yapmıştır. Aynı zamanda çocukluğun dönemlendirilmesi ve çocukluktan yetişkinliğe geçişin hangi aşamalardan geçilerek sağlandığının anlaşılmasına da önemli katkılarda bulunmuştur. ${ }^{2}$

Tanzimat dönemine kadar Osmanlı toplumunda çocuğun farklı ve müstakil bir konumunun olmadığı; yayınlanan eserlerde, çocuklara ve çocukluğa özel bir yerin neredeyse verilmediği ya da 19. yüzyıl ortalarına kadar çocuklara dair özel yaşama alanlarının ve giysilerinin olmadı̆̆ı; çocukların "minyatür yetişkinler" olarak algılandığı iddia edilse de ${ }^{3}$ Yahya Araz'ın da ifade ettiği gibi çocukluğun ve çocukların yazılı metinlerde dikkate alınmadığı ile ilgili düşünceleri sahiplenirken acele edilmemesi gerektiğidir. Nitekim çocukların yetiştirilmesine adanmış terbiye kitaplarının varlığı bile bu husustaki iddialarda temkinli olunmasını gerektirmektedir. ${ }^{4}$ Ahlâk eserlerinde çocukla ilgili meseleler genellikle çocuğun doğumundan önceki eğitimle başlayıp, yetişkin bir birey olduğu döneme kadar olan eğitimi kapsamakta ve çocuk konusu üzerinde itina ile durmaktadır. ${ }^{5}$

İslamiyet'te kimsesiz, fakir ve dulların korunmasının dini bir emir olması, Kuran-1 Kerim'de yetimlerle ilgili ayetlerin yer alması, Osmanlı Müslümanlarında yetimlere ihtimam

\footnotetext{
${ }^{1}$ Bekir Onur, Türkiye'de Çocukluğun Tarihi, İmge Kitabevi, Ankara 2005, s. 60-61.

${ }^{2}$ Yahya Araz, 16. Yüzyıldan 19. Yüzyll Başlarına Osmanlı Toplumunda Çocuk Olmak, Kitap Yayınevi, İstanbul 2013, s. $17-18$.

${ }^{3}$ Güven Gürkan Öztan, Türkiye'de Çocukluğun Politik İnşası, İstanbul Bilgi Üniversitesi Yayınları, İstanbul 2013, s. 34.

${ }^{4}$ Araz, age, s. 21.

${ }^{5}$ Hatice Toksöz, "Osmanlı Klasik Dönem Ahlak Eserlerinde Çocuk eğitimi”, Osmanlı Dünyasında Çocuk Olmak, Ed. Haşim Şahin-Nurdan Şafak, Değerler eğitimi Merkezi Yayınları, İstanbul 2012, s. 90-91.
} 
gösterilmesinin dini ve sosyal bir gereklilik olarak algılanmasını sağlamıştır. Bunun yanı sıra yüzyıllar boyunca Osmanlı dünyasında Müslüman kimsesiz, yetim ve yoksulların ihtiyaçlarının önemli bir kısmı vakıflar tarafından karşılanmıştı. Osmanlı sistemi içinde vakıflar, sosyal dengenin sağlanması için önemli işlevler gördü. Nitekim 19. yüzyılın ikinci yarısından sonra vakıflar tarafindan sunulan hizmetler, devletten beklenir hale geldi. Devlet ve bazı cemiyetler kimsesiz çocuklar için sosyal kurumlar inşa etme yoluna gitti. ${ }^{6}$

Çocuk açısından gerçekte bütün ihtiyaçlarının fedakârca ve doğru bir şekilde karşılanabileceği en köklü müessese teorik olarak aile olsa da ailede meydana gelen ölüm, terk etme/edilme, boşanma, yoksulluk gibi nedenlerle çocuklar korunma ve himaye yönünden başkalarının vesayetine ihtiyaç duymaktaydılar. Bu durumdaki çocuklar Osmanlıda hukuken himaye ve koruma altına alınarak sağlıklı bir şekilde hayata tutunmaları hedeflenmiştir. Mümkün olduğunca, sokaklara terk edilmemiş, anne babasını kaybedip yetim kalan çocuklar rastgele ve herhangi birinin veya akrabasının inisiyatifine bırakılmamıştır. Devlet, şer'i mahkemeler vasıtasıyla, yetim ve kimsesiz kalan çocukların aile terbiyesi ve kültürünü almaları noktasında vasilik ve nâzırlık adıyla tutanaklara geçen bir düzen kurmuştur. ${ }^{7}$

Osmanlı Devleti'nde yetim ve öksüzleri korumaya yönelik faaliyetler Tanzimat öncesinde gayr-i resmi olarak, Tanzimat'tan sonra ise resmilik kazanarak var olmuştur. Nitekim söz konusu dönemde yetimlere sahip çıkma bağlamında birtakım nizamnameler hazırlanmış ve bu nizamnameleri hayata geçirmek üzere idari mekanizmalar vücuda getirilmiştir. Özellikle Tuna Valisi Mithat Paşa, 1860'larda Müslüman ve Hristiyan bazı bakımsız ve yetim çocuklarının perişan ve yoksulluğunu düşünerek bu çocuklara yardımseverlerden topladığı yardımlarla terbiye edilmelerini ve sanat öğrenmelerini temin için Niş, Sofya ve Rusçuk'ta birer islahhane açmıştır. Abdülaziz döneminde açılan Darüşşafaka ve II. Abdülhamid döneminde açılan Darülaceze ile Darülhayr-1 Âlî amaç ve faaliyet yönüyle birbirine benzer kurumlar olarak işlev görmüşlerdir. ${ }^{8}$ Bu bağlamda dikkat çeken çalışmalar ve faaliyetlerde bulunan II. Abdülhamid dönemi dikkate değerdir. II. Abdülhamid döneminin dikkat çeken hususlarından birisi Padişah'ın kendi şahsıyla bütünleştirdiği sosyal kurumları açtırmış olmasıdır. Abdülhamid fakir ve muhtaç Osmanlı tebaasını koruma arzusu içerisinde çeşitli ihsan ve atiyye-i seniyyelerle bu arzusunu gerçekleştirmiştir. Özellikle döneminde açılan Hamidiye Etfal Hastanesi ve Darülaceze gibi kurumlar aracılığıyla yardıma muhtaç kimselerin elinden tutmuştu. Hamidiye Etfal Hastanesi'nin kuruluş öyküsü Padişah'ın kızı Hatice Sultan ile alakalıydı. Kızı Hatice Sultan'ın hastalık sonucu vefatından çok etkilenen II. Abdülhamid, ülkesindeki fakir çocuklara hizmet verecek modern bir çocuk hastanesi kurulması kararını almıştı. Hastanenin denetimi doğrudan Padişah’ta olmuş ve mali olarak Hazine-i Hassa-i Hümayun tarafindan desteklenmiştir. Açıldığı dönemde modern tıbbın bir yansıması olarak görülen hastane Avrupalı doktorların bile ilgisini çekerek Abdülhamid'in prestij kaynağı da olmuştur. ${ }^{9}$

1896'da Osmanlı Devleti'nin en önemli sosyal kurumlarından biri olan Darülaceze'nin açılması ise hem prestij hem de ihtiyacı karşılama bağlamında ciddi bir adım olmuştu. Nitekim

\footnotetext{
${ }^{6}$ Nurdan Şafak, “Osmanlı İmparatorluğu’nda Kimsesiz Çocuk Olmak ve Islahhaneler (1863-1903)”, Osmanll Dünyasında Çocuk Olmak, Ed. Haşim Şahin-Nurdan Şafak, Değerler eğitimi Merkezi Yayınları, İstanbul 2012, s. 134135.

${ }^{7}$ Ahmet Gündüz, “Osmanlı'da Kimsesiz Çocukların Himaye ve Korunması: Antakya Örneği (1860-1900)”, Geçmişten Günümüze Şehir ve Çocuk II, Ed. Osman Köse, Canik Belediyesi Kültür Yayınları, Samsun 2016, s. 790.

${ }^{8}$ Ersin Müezzinoğlu, "I. Dünya Savaşı Esnasında Yetim ve Öksüz Çocukların Himayesi ve Eğitimi: Darüleytamlar", History Studies, 4/1, 2012, s. 400.

${ }^{9}$ Nadir Özbek, "II. Abdülhamid ve Kimsesiz Çocuklar", Tarih ve Toplum, S. 182, Şubat 1999, s. 75.
} 
dilencilik önlenmeye ve suç oranları asgari seviyeye düşürülmeye çalış1ldı. Öte yandan kimsesiz, muhtaç, yaşlılar ve engellilere devlet eli ile kurumsal bir himaye sağlanmaya çalışılmıştı. ${ }^{10}$

Erken Cumhuriyet yıllarında İstanbul Şehremaneti Mecmuasında yayınlanan bir yazıda Darülaceze'den şu şekilde bahsediliyordu:

"Darülaceze... Şehirden uzakta, Kağıthane Deresi sirtlarında kain bir yurt. Bütün sekenesi beşiktekinden memat eşiğindekine kadar cümlesi Türklük camiasının en bedbaht ve en muhtaç himaye ve tesli kısmı. Hayatı çok yakından tanımış, mesut günler yaşamış erkeklerden, kadınlardan hayata gelir gelmez bir cami kenarına, kuru bir çeşme yalağına bırakılıvermiş; anası, babası meçhul çocuklardan müteşekkil siyah tüllü bir alem. Bunların tek melceleri penah-1 tesliyetleri Darülaceze ismi verilen bu şefkat yurdudur.

Ben Darülacezeyi ekserimiz gibi yalnız ölüme yaklaşan kimsesiz ihtiyarların birkaç gün misafir kaldıkları basit bir mekân zannederdim. Gezdim ve içinde çalışım da. Gördüm ki bu zannım çok yanlı̧̧ış. Darülaceze hastanesi, ırzahanesi (emzirme evi, süt çocuğu yuvası, kreş) ve mektebi ile mühim ve geniş bir müessese, bir müessese-i Hayriye ve sanaiyedir. Adeta Darülaceze sekenesiyle tesisatıyla başlı başına bir şehirdir." 11

İstanbul Şehremaneti Mecmuasındaki yazıdan da anlaşılacağı üzere Darülaceze sadece ihtiyarları misafir etmiyordu. Özellikle kimsesiz ve muhtaç çocuklara da kucağını açıyordu. ${ }^{12} \mathrm{Bu}$ noktada çocuklar için gayet donanımlı ırzahanenin açılması çok önemliydi. Bu hem devletin prestij kazanmasında hem de çocukların hayatta kalmasında önemli bir rol üstlenmişti. Darülaceze'de kimsesiz ve yoksul çocukların barındığı bu müessesenin "irzahane" veya "dârülırza" gibi iki farklı kullanımı vardı. Bu kelimeler emzirme evi anlamına gelmekte olup "kreş/süt çocuğu yuvası" karşılığında kullanılmıştır. 1903'te hizmete açılan ırzahanenin kapısının üzerinde "irzahane-creche" tabelası bulunurken salonundaki duvarda ise son beytinde ırzahanenin açılıș yılının belirtildiği şiir asılıydı. Sokağa terk edilmiş yeni doğmuş süt çocuklarının bakıldığı kreşe lakita ${ }^{13}$ dairesi de deniyordu. Darülaceze'nin açıldığı ilk yıllarda süt çocuklarına ayrılmış özel bir alan yoktu. Dahiliye Nazırı Memduh Paşa'nın önerisi üzerine Padişah'ın iradesiyle dairelerden bir tanesi 1rzahane haline getirildi. ${ }^{14}$ Irzahane, Darülaceze içinde sıfir-yedi yaş çocukları için açılmış olan süt emzirme dairesi olarak yerini aldı. Bu dairede özellikle terk edilmiş çocuklar bulunuyordu. ${ }^{15}$ Farklı kaynaklarda ve belgelerde burada bakılan çocukların üç yaşına kadar ya da üç dört yaşına kadar bulunduğu belirtilmektedir. Buradaki çocuklar ikinci çocukluk dönemini darülaceze içinde açılacak olan yetimhanede geçirecek ${ }^{16}$ ve

\footnotetext{
${ }^{10}$ Öztan, age, s. 42.

${ }^{11}$ İstanbul Şehremaneti Mecmuası, 30 Teșrinîsânî 1341/30 Kasım 1925, C. 2, S.16, s. 108-110.

${ }^{12}$ Fiziki olarak doğum anından itibaren yürüme dönemine kadar olan zaman diliminde yeni doğan çocuklar bebek olarak tanımlanıyor olsa da bu çalışmada tamamı çocuk olarak ifade edilmiştir.

${ }^{13}$ Sahipsiz, buluntu çocuk anlamında kullanılan bir fıkıh terimi olan lakit ile ilgili ayrıntılı bilgi için bkz.; Saffet Köse, "Lakit", Türkiye Diyanet Vakfi İslam Ansiklopedisi, C. 27, Ankara 2003, s. 68-69.

${ }^{14}$ Nuran Yıldırım, İstanbul Darülaceze Müessesesi Tarihi, Darülaceze Vakfı Yayınları, İstanbul 1996, s. 162.; Nuran Yıldırım, "Darülaceze'de Çocuk Bakımı ve Eğitimi-Lakita Dairesi ve Yetimhane, İmalathaneler, İlkokul", Toplumsal Tarih, 264, Aralik 2015, s. 26-27.

${ }^{15}$ Darülaceze, kimsesiz çocukları, yaşlı ve muhtaçları barındırmak amacıyla 1896 yılında Padişah II. Abdülhamid'in isteğiyle açılmış bir hayır kurumudur. II. Abdülhamid 30 Mart 1890'da dilencilik yapan, sokaklarda dilenen kimsesiz çocukları; herhangi bir engeli bulunan kadın ve erkekleri dilenme zilletinden kurtarmak; kimsesizlerin eğitim ve bakımlarını sağlamak amacıyla proje üretilmesini istemiştir. İsminin "Darülaceze" olacağını bizzat kendisi karar vererek inşaat çalışmaları ve diğer birtakım hazırlıklarını tamamlayan Darülaceze, 2 Şubat 1896'da açıldı. Hidayet Y. Nuhoğlu, "Dârülaceze", Türkiye Diyanet Vakfi İslam Ansiklopedisi, C. 8, İstanbul 1993, s. 512-514.

${ }^{16}$ Ehâsin-i Müessesât-ı Hayriye-i Hazret-i Hilâfet-Penahîden Darülaceze, Mihran Matbaası, İstanbul 1324.; Öztan, age, s. 42.
} 
böylece yetimhane irzahaneyi tamamlayan bir kurum olacaktı. ${ }^{17}$ Irzahanedeki bu çocuklar anasız, babasız, sütninesiz kalmış, düşkün çocuklar, terkedilmiş veya sokağa bırakılmış çocuklar arasındaki süt emmeye muhtaç olan yavrulardı. Yeteri kadar beslenemeyen bu çocuklar ölüme mahkûm oluyorlard. ${ }^{18}$

\section{Irzahanenin Kuruluşu ve Özellikleri}

II. Abdülhamid'in fermanı üzerine Dahiliye Nazırı ırzahanenin açılması için hazırlıklara başlamıştı; çünkü ırzahane sadece çocukların ölüm oranlarını azaltmakla kalmayacak aynı zamanda Osmanlı Devleti'nin ve İslam'ın şanını da yükseltecekti. Darülaceze içerisine yapılan bir daire olan ırzahane hem bir emzirme evi olmuş hem de burada çağdaş sağlık uygulamaları yapılmaya başlanmıştı. ${ }^{19}$

Irzahanede önemli hususlardan olan beslenme, bakım ve giyim meseleleri ayrıntılarına kadar düşünülmüştü. Örneğin dairenin içi Viyana'dan özel olarak getirilen üzeri mikrop tutmayan özellikte bir boya ile boyanıyordu; kollarındaki beyaz bantlar üzerinde "Darülaceze Emzirme Evi" yazılı dadılar getirilmişti; dairenin içi muşamba ile döşenmiş, ütülenebilir patiska perdeler tercih edilmiş; hastalar, küçükler, biraz büyükler için ayrı daireler tahsis edilmişti. Çocukların beslenmesi konusu da titizlikle ele alınmış; darülacezenin yanındaki ahırda beslenen ineklerin sütleriyle bebekler beslenmişti. ${ }^{20}$

Çocukların gelişiminin sağlıklı olması, düzenli bir şekilde kilo almalarıyla da alakalıydı. Bunun için ırzahanede bulunan çocuklar her gün tartılıp kayıt altına alınıyordu. Kayıtlarda herhangi bir yanlışlığa sebep olmaması için de her çocuğa bir numara veriliyordu. Darülaceze'de Çocuk Hastalıkları Uzmanı Kadri Raşit; her hafta tartılıp ağırlıklarının kaydedildiği defteri incelediğinde çocuklara dair birçok sorunu çözebildiğinden bahsediyordu. Dr. Kadri Râşit Bey; "Zayıf olan çocuklarla, normal hallerinde kalıp kilo almış çocukların elini kolunu muayene ettim, bakacılarını sorguya çektim, dışkılarını gördüm. Hiçbirinin gıda azlığından zayıflamadığını, gıdanın çokluğundan dolayı kilo almadıklarını fark ettim. Perhiz ettirdim, bağırsaklarını, midelerini tedavi ettim, çocuklar iyileşmeye başladılar. Çocukların aldĭ̆ı sütün miktarını azalttım, iki süt alma zamanının arasını açtım; çocuklar kilo aldı." Şeklinde çocukların beslenmelerine dair fikirlerini bildirmiştir. ${ }^{21}$

Irzahanenin Darülaceze'deki görünümüne dair betimlemeler yapan Besim Ömer'e göre içi, dış1, bütün manzarası çocukluk kadar saf, berrak, temiz, hoştu. İnsanın burada bulundukça her an, her lahza başka bir hoşluk ve güzelliği karşısında bulabileceğini ifade etmektedir. Hatta ırzahane ziyaretinde karşılaşmış olduğu tablo oradaki bebeklerin ne şartlarda yaşadığını gözler önüne sermesi açısından dikkate değerdir. Şöyle ki çocukların ihtimamlı, gayretli, temiz ve müşfik kadınların önlerinde mini mini arabalara dizilmiş bir halde etrafı seyretmeleri; havanın güzelliğinden istifade etmeleri mesut ve müreffeh aile çocuklarında bile görülemeyen bir saadet haliydi. Arabaların şıklığı, temizliği, rahatlığı, çocukları idare edenlerin dikkat ve gayretleri, 1rzahanedeki çocukları analı babalı çocuklar kadar zinde gösteriyordu. ${ }^{22}$

İncelendiğinde bu rrzahanenin Avrupa'nın en son bilimsel tekniklerine göre donatılmış olduğu görülmektedir. $\mathrm{Bu}$ yönüyle de kurum Osmanlı Devleti’nin ve hükümdarının

\footnotetext{
${ }^{17}$ Mucize Ünlü, "II. Abdülhamid Döneminde Balkanlarda Fakir ve Kimsesiz Çocuklar”, Geçmişten Günümüze Şehir ve Çocuk II, Ed. Osman Köse, Canik Belediyesi Kültür Yayınları, Samsun 2016, s. 810.

${ }^{18}$ Ehâsin-i Müessesât-ı Hayriye-i Hazret-i Hilâfet-Penahîden Darülaceze, s. 46.

${ }^{19}$ Age, s. 46.

${ }^{20}$ Age, s. 46.

${ }^{21}$ Kadri Raşit, "Çocukları Tagaddiye”, Ehâsin-i Müessesât-ı Hayriye-i Hazret-i Hilâfet-Penahîden Darülaceze, s. 62.

22 Besim Ömer, Darülaceze Irzahanesi, Ahmed İhsan ve Şürekas1 Matbaası, İstanbul 1319, s. 21-23.
} 
modernleştiğini temsil etmektedir. Öte yandan dünyada çocuk sorununa artan ilginin, II. Abdülhamid döneminde nasıl bir şekil kazandığını gözler önüne sermesi açısından da önem taşımaktadır. ${ }^{23}$

Irzahanenin modern yöntemlerle kurulduğu ve işletildiğinden bahsedilmişti. Nitekim Darülaceze müdürünün bir buçuk ay süreyle Almanya'ya gitmesi de bunun en açık kanıtıdır. Darülaceze müdürü bu ziyareti ile irzahane ve buna benzer müesseselerin teşkilat ve idareleri hususunda Almanya'da incelemelerde bulunmuştur. ${ }^{24}$

Irzahane, dönemi itibariyle her türlü teknik donanıma sahip olduğu için insanların hayran oldukları bir yapıydı. Sokakta terkedilmiş yavruların yoksul ve dul kalan anneleri burada çocuklarına gösterilen ihtimam karşısında hayranlıklarını dile getiriyordu. ${ }^{25}$ Nitekim yoksulluk çeken bir annenin henüz süt çocuğunu irzahaneye teslim etmesi ve sonrasında yaşamış olduğu durum bunun en güzel örneğidir. Kadın çocuğunu besleyemediği için ırzahaneye bırakır; fakat anne yüreği bu duruma fazla dayanamaz, hizmetçilik yapmaya başlayıp para kazanınca iki üç ay içerisinde çocuğunu almaya gider. Gittiğinde görmüş olduğu manzaraya hayran kalır. Çünkü karyolalar, çarşaflar tertemizdir; hizmetçiler özenle seçilmiş ve ellerinde hem besleyici hem de bol gıdalar vardır. Gittiğinde çocuğunun hem kilo aldığını görmesi hem de rahatça uyuyor olması biçare anneyi mutluluğa boğar; Padişah'a hayır duaları ederek ve kendi kucağının çocuğuna bu saadeti veremeyeceğini ifade ederek çocuğunu irzahaneden almaktan vazgeçer. ${ }^{26}$

Irzahanenin modern cihazlarına ciddi paralar harcandığı örneklerde görülmektedir. Mayıs 1903 'te irzahanede eksikliği hissedilen kovozolyon cihazının temin edilmesi ile ilgili girişimler sonuç vermiş ve 400 frank değerindeki cihaz müessesenin kuruluşunun ardından hemen temin edilmişti. $^{27}$

Çocukların ve müessesedekilerin sağlığını öncelemek ve herhangi bir salgın hastalıkla baş edebilmek için müesseseye ilaveten; fakat müesseseden ayrı bir yerde bir de "tecrit pavyon" unun inşası gerekiyordu. Çünkü toplu yaşadıkları için herhangi bir çocukta bulaşıcı hastalık ortaya çıksa hepsine bulaşabilirdi. Ayrıca sineklerden kaynaklı hastalıkların önüne geçebilmek adına pencerelere gayet ince tel kafesler geçirmek uygun olabilirdi. Bu tür ilave tedbirlerle çocuklar her türlü hastalıkların kızılın, kızamığın, su çiçeğinin, kuş palazının, horoz öksürüğünün hatta veremin, ishallerin önüne geçmiş olacaklard.$^{28}$

Irzahanede yukarıda da bahsedildiği üzere her türlü ayrıntı düşünülmüştü. Avrupa fabrikalarının en iyi ürünlerinden karyolalar, çocukların beslenmesi için en halis sütler, modern teknolojiye uygun pastörize evi, sütlerin saklanması için buzdolapları, tıbbî ve teknolojik araç gereç, beden sağlıklarını önceleyen banyolar, çocukların her türlü beslenme ve temizlik ihtiyaçlarını gideren dadılar, hizmetçiler, çamaşırcılar, doktorlar, ilaçlar, oyuncaklar mevcuttu. Ayrıca ırzahanenin dört yataklı küçük bir hastanesi, küçük bir eczanesi, beşer yataklı müşahede ve yeşil ishalliler salonu da yine çocuklar için hizmete hazırdı. ${ }^{29}$ Zira bütün bu hazırlık ve çalışmalar çocuk ölümlerinin önüne geçmede yeterli olmayacaktı.

${ }^{23}$ Nadir Özbek, Osmanlı Imparatorluğu'nda Sosyal Devlet-Siyaset, İktidar ve Meşruiyet 1876-1914, İletişim Yayınları, İstanbul 2011, s. 209-210.

${ }^{24}$ BOA (Türkiye Cumhuriyeti Cumhurbaşkanlığı Devlet Arşivleri Başkanlığı Osmanlı Arşivi) Umûr-ı Mahalliyye-i Vilayât Müdürlüğü, (BOA. DH. UMVM.), 113/27, 12 Kasım 1917 (27.01.1336).

${ }^{25}$ Ehâsin-i Müessesât-ı Hayriye-i Hazret-i Hilâfet-Penahîden Darülaceze, s. 49.

${ }^{26}$ Age, s. 47.

${ }^{27}$ BOA, Dahiliye Nezâreti Mektubî Kalemi (DH. MKT.), 727/40, 22 Haziran 1903 (26.03.1321).

${ }^{28}$ Besim Ömer, age, s. 32.

${ }^{29}$ Ehâsin-i Müessesât-ı Hayriye-i Hazret-i Hilâfet-Penahîden Darülaceze, s. 49. 


\section{Irzahane Teşkilatı}

Yoksul çocukların bir anne şefkatiyle bakılıp beslendiği ırzahane heyeti toplamda on altı kişiden ibaretti. Bunlar; bir Müdür, bir mubassır, sekiz dadı, iki hademe, sağl1klı ve hasta çocuklar için birer tane çamaşırcı, süt ile ilgilenen bir kişi ve bir de kapıcıdan oluşmaktaydı. ${ }^{30}$

1913 tarihli Darülaceze Talimatnamesinin üçüncü, beşinci, on ikinci, on üçüncü, otuz yedinci ve otuz sekizinci maddelerinde 1rzahanede görevli kişilerin kimler olduğu ve görevlerine dair bilgiler mevcuttu. Bu talimatnamenin üçüncü maddesinde bir tane 1rzahane doktorunun olduğ ${ }^{31}$, beşinci maddesinde ise ırzahane mubassırının, sütninenin, dadının görevli olduğu belirtilmiştir. ${ }^{32}$ Talimatnamede on ikinci maddeyle irzahane hekiminin görevleri belirtilmiştir.

Irzahanedeki hekimin görevi; her gün rrzahaneye gelerek burada bulunan yeni doğmuş çocukları muayene odasında kontrol etmek; hasta olan çocukların kontrolünü yapmaktı. Buradaki hekim genel olarak çocukların sağlı̆̆ından sorumlu olduğu gibi süt takımlarının temizlik ve bakımını gözetmekle de yükümlüydü. Ayrıca Darülaceze'ye gelecek olan çocuk doktorunun önerdiği tedbirleri yerine getirmek de görevli hekimin işiydi. ${ }^{33}$ Çocuk doktorunun vazifesi madde on üçte açıklanmıştır. Irzahanede mevcut bebek ve çocukların hastalıklarını teşhis etmek ve tedavilerini yapmakla görevliydi. Ayrıca haftada üç defa müesseseye gelmekle de yükümlüydü. ${ }^{34}$

Darülaceze talimatnamesinde mubassırların görevlerine dair açıklamalar madde otuz yedide belirtildiği şekliyle; çocukların temizlenmesinde yani banyolarının yapılması, bezlerinin temiz bulunması ve kundaklarının ve çamaşırlarının düzenli tutulması, çocukların bulundukları odaların derecesini uygun hale getirmek, çocukları cereyandan sakınmak; ırza sanayi ile beslenen çocukların süt şişesiyle memeliklerinin daima kaynamış bulundurulması ve süthanede bulunan edevat takımının daima temiz ve hekimlerin tarifiyle bir intizam içerisinde düzeltilmesi; sütlerin bozulmadan muhafaza edilmesi; çocuklarda herhangi bir olumsuz durum gördüklerinde hekime haber vermeleri ve hekimlerin ilaçla ya da bakımlarına dair tavsiyelerini yerine getirmeleri; çocukların bakımını üstlenen diğer görevlilerin dadı, sütnine ve çocuk bakıcılarının vazifelerini kontrol etmek ve kendilerine teslim edilen eşyaların ziyan olmasından da sorumlu tutulmuşlard..$^{35}$

Sütnine ve dadının vazifeleri ise madde otuz sekizde açıklanmıştır. Görevleri arasında yeni doğmuş bebekleri hekimlerin belirttiği şekilde beslemeleri; yine hekimlerin tarifiyle bebekleri emzirmeleri; çocukların temizliği ve güzel giydirilmeleri hususunda birlikte hareket etmeleri belirtilmişti. Ayrıca bebeklerin bakıldığı dairedeki bütün eşyaların temiz tutulmasından, zarar görmemelerinden de sorumluydular. ${ }^{36}$

Irzahane dairesinde mürebbiyelerin seçimi de önemliydi ve zaman zaman bu konuda görev değişikliği ya da boşalan kadroyu doldurmada sıkıntılar yaşanmaktaydı. Örneğin Ekim 1905'te Darülaceze 1rzahanesi mürebbiyesi olarak çalışan Madam Golye'nin istifa etmesi üzerine mürebbiyelik görevini yerine getirecek Katya Hevir ve Natalia Belman adındaki iki Alman kadın Madam Golye'den boşalan mürebbiyeliğe 400 kuruş maaşla tayin edilmişlerdi. Darülaceze 1rzahanesi ve eytamhaneleri, Katya Hevir ile Entvan istifa ettikleri gibi Natalia Belman dahi işten çıkma niyetinde bulunduklarını Darülaceze müdüriyetine bildirmişlerdi. Birkaç ay öncesine

\footnotetext{
${ }^{30}$ Besim Ömer, age, s.34.

${ }^{31}$ Darülaceze Talimatnamesi, Ahmed İhsan ve Şürekası Matbaacılık Osmanlı Şirketi, İstanbul 1329, s. 4.

${ }^{32}$ Age, s. 4.

${ }^{33}$ Age, s. 10.

${ }^{34}$ Age, s. 11.

${ }^{35}$ Age, s. 33

${ }^{36}$ Age, s. 33.
} 
kadar ırzahanede mürebbiye olarak istihdam edilen ve bu işlerde ihtisas sahibi olduğu bilinen Madam Golye 400 kuruş maaşla Kasım 1905'ten itibaren tekrardan 1rzahane ve eytamhaneye tayin edildi. ${ }^{37}$

Bununla birlikte 1rzahanede yolunda gitmeyen bazı sıkıntılı durumlar olduğu da iddia ediliyordu. Örneğin 1rzahanenin lakita dairesi müdürü olan Françoise Baldy, lakita dairesindeki çocukların iyi beslenip tedavi edilmediklerini Başhekim Dr. Derviş Bey’e bildirdiğinden dolayı görevinden alındığına dair 21 Temmuz 1903 'te dilekçe yazmıştı. Dilekçesinde kendisinin haksız yere görevinden alındığını; tekrardan görevine iade edilmesini istemişti. Bu olay üzerine durumun incelenmesi ve yanlışlığın düzeltilmesi emredildi. ${ }^{38}$

1906 yılında 1rzahane müdürü Dr. Kadri Raşit Bey’di. O yıl kreşte 38 bebek bulunuyordu. 1908 yılına gelindiğinde Madam Golye'nin beş sütnine, on dadi ile hala görevli olduğu görülmektedir. Meşrutiyet’ten sonra 1rzahane "İstanbul Darülaceze Süt Çocukları Yuvası" adını almıştır. Bu tarihten itibaren çocuklar kalıcı bir hekim tarafindan muayene edilmeye ve belirli saatlerde beslenmeye başlanmıştı. Çocuklar için tutulan özel deftere bütün bebeklerin beslenme biçimi, ağırlığı, içtiği sütün miktarı, süte ne kadar şeker ve su katıldığı, beden 1sısı ve dışkısı kaydediliyordu. ${ }^{39}$ Böyle titiz bir çalışma şekli çocuklarda herhangi bir hastalık görüldüğü takdirde ne şekilde tedavi uygulanabileceğini göstermesi açısından da önemliydi.

Çocukların bakımıyla ilgili çalışmaların I. Dünya Savaşı yıllarında ve sonrasında da devam ettiği görülmektedir. Nitekim savaş döneminde kimsesiz ve yoksul çocukların sayılarının artışı bunu gerekli kılmıştır. Süt çağındaki çocukların anneleri dışındaki kişiler tarafından bakım ve ihtiyaçlarının karşılanması ciddi profesyonellik isteyen bir durumdu. Profesyonelliğin tıbbi bilimlerle de desteklenmesi gerekiyordu. Yalnızca dişardan temin edilen mürebbiyeler ve dadılarla çocuk ölümlerinin önüne geçmek mümkün olmuyordu. Bunun için I. Dünya Savaşı'nın en buhranlı günlerinde profesyonel kişilerin Darülaceze bünyesinde istihdam edilmeleriyle ilgili çalışmalar yapıldı. Bunun sonucunda Osmanlı'nın en büyük müttefiki olan Almanya'dan üç hemşirenin getirilmesine karar verildi. Kayzerin Ogusta Viktorya Havz isimli müessese ile yapılan anlaşmaya göre Berlin'den getirilecek üç hemşire kurumda istihdam edilecekti. Hemşirelerden biri süthaneye, ikincisi hasta çocuklara, üçüncüsü ise sağlıklı çocuklara bakmakla yükümlü olacaklard1. ${ }^{40}$

Irzahanede görev yapan Doktor Mecid Bey'in yerine üç seneden beri Etfal Hastanesinde emraz-1 hariciye muavinliğinde bulunan Doktor Yusuf Ziya Bey'in 1.250 kuruş maaşla tayini 7 Aralık 1918 'de gerçekleşmiştir. ${ }^{41}$

Darülaceze ırzahane Hekimi Ali Şükrü Bey, yakalandığı zatürre hastalığının tedavisi için Berlin'e izinli olarak gitmiş; fakat aradan geçen zaman içerisinde iyileşemeyince izin süresinin uzatılmasını talep etmiştir. Eylül 1921 'de bu istek uygun görülmüştür. ${ }^{42}$ Fakat kısa süre içerisinde Ali Şükrü Bey görevinden istifa etmek zorunda kalmış; yerine ise Operatör Doktor Emin Bey Ekim 1921'de tayin edilmiştir. ${ }^{43}$

1920 yılında Darülaceze'de 12.000 çocuğun olduğu, kurulduğu günden itibaren ise 23.105 çocuğa bakıldığı bilinmektedir. Bu dönemde her iki çocuğa bir sütnine düşüyordu. Sütninelerin

${ }^{37}$ BOA, DH. MKT., 1022/26, 31 Ekim 1905 (02.09.1323).

${ }^{38}$ Yildırım, agm, s. 26-27.

${ }^{39}$ Yildırım, age, s. 163.

${ }^{40}$ BOA, DH. UMVM., 149/46, 30 Temmuz 1917 (10.10.1335).

${ }^{41}$ BOA, DH. UMVM., 156/102, 14 Aralı 1918 (10.03.1337).

${ }^{42}$ BOA, DH. UMVM., 165/5, 10 Eylül 1921 (07.01.1340).

${ }^{43}$ BOA, DH. UMVM., 165/38, 26 Ekim 1921 (23.02.1340). 
vazifeleri doktorun tavsiye ettiği beslenme şeklini uygulama, çocukların banyolarını yaptırıp onları gözetim altında tutmalarıydı. Çocuklar 5 yaşına geldiğinde bitişik koğuşa geçirilirken burada da yine yedi yaşına kadar doktor gözetiminde bakılıyorlar, bu yaştan sonra aşağı koğuşa indiriliyorlard1. ${ }^{4}$

Dr. Safiye Ali'nin ${ }^{45}$ kadınlar ve çocuklar ekseninde tıp tarihine katkıları özellikle sağlıklı çocuk büyütmek anlamında önem arz ediyordu. Almanya'da eğitimini tamamlayıp çocuk hastalıkları ve jinekoloji uzmanlığını aldıktan sonra ülkesine dönen Dr. Safiye Ali, sağlıklı çocuk büyütmenin ancak anneleri eğitmekle mümkün olabileceğini benimsediğinden, İstanbul'daki anneleri çocuk sağlığı ve güncel-modern annelik uygulamaları, koruyucu sağlık önlemleri konusunda bilgilendirmek için Hilal-i Ahmer Cemiyeti Hanımlar Merkezi Küçük Çocuklar Muayenehanesinde çalışmaya başlamıştı. Sonrasında ise işgal dönemi Fransız generallerinden Palle'nin girişimiyle Fransız Kızılhaç örgütünde görevli kadınların 1922 yılında yoksul çocuklara yardım amacıyla kurdukları "süt damlası" isimli dernek, 1924 yılından itibaren Himaye-i Etfal Cemiyeti'ne devredilerek zamanla Besim Ömer Paşa'nın etkisiyle tıp öğrencileri ve ebeler için uygulamalı eğitim görebilecekleri bir klinik halini almıştır. 1926 yılından itibaren Dr. Safiye Ali bu kurumun müdürü olmuş ve sağlıklı ve bilinçli çocuk bakımının nasıl olması gerektiği üzerine eğitimler vermek öncelikli hedefi haline gelmişti. ${ }^{46}$ Süt damlası sayesinde yeterli ve sağlıklı beslenemeyen çocuklar beslenerek, çocuk ölümlerinin önüne geçilmeye çalış1lmıştır.

1926'da Darülaceze'ye getirilen yeni doğmuş çocukların kurum dışında emzirilmelerinin sağlanması için müracaat eden sütninelere verilmeleri uygun görülmüş ve karar uygulanmaya başlanmıştı. Kuruma müracaat eden sütninelerin sıhhi durumlarında herhangi bir bozukluk görülmediği takdirde peyderpey çocuk veriliyordu. Bu bir takım yanlış uygulamaları da beraberinde getirdi. Şöyle ki sütninelerin evlerinde sağlıkları bozulan çocukların müessese doktorları tarafından muayene ve tedavilerinde para talep edilmeye başlandı. Müessese tarafindan bu gibi durumlarda doktorların herhangi bir ücret talep edemeyecekleri yalnızca kendilerine müteferrika tertibinden yol parası ödenmesi uygun görüldü. ${ }^{47}$

\section{Irzahanede Emzirme ve Beslenme}

Irzahane içerisinde bebeklerin süt ihtiyacının karşılanması oldukça dikkat ve ehemmiyet isteyen bir durumdu; çünkü bebeklerin hayatlarının devamı, sağlıklı olmaları süte bağlıydı. Bebeklerin yegâne gıdası olan sütün saklanması ve emzirilmesi konusunda yapılacak olan ufak hatalar bile çok büyük ve vahim sonuçlar doğurabilirdi. Nitekim annesinin sütü olmayan, sütanne bulamayan ya da sütanne tutmaya gücü yetmeyen aileler çocuklarını emzikle beslemek zorunda kalıyorlardı. Bu durumda da yeni riskler ortaya çıkma ihtimali hep oluyordu. Örneğin sütün uygunsuz saklanması ya da süte fazla su katılması veya emzik şişelerinin iyi temizlenmemesi bebeklerin sağlığını tehlikeye atan etmenler arasındaydı. Bu şekilde beslenmeyle bebeklerde rahatsızlıklar, hastalıklar görülme ihtimali artıyordu. ${ }^{48}$

19. yüzyılda "sterilize edilmiş süt ve biberonların" kullanılmaya başlandığı tarihlere kadar anne sütünün tek alternatifi sütannenin sütüydü. $\mathrm{Bu}$ dönemde tabipler sterilizasyon sorununun farkındaydı. Öte taraftan hem İslam hem de Batı dünyasında çocukların emdikleri süt yoluyla,

${ }^{44}$ Akşam, 25 Nisan 1336/25 Nisan 1920, No. 574.

${ }^{45}$ Safiye Ali'nin hayatına dair ayrıntılı bilgi için bkz.; Nuran Yıldırım, Türkiye'nin İlk Kadın Doktoru Safiye Ali, Tarih Vakfi Yurt Yayınları, İstanbul 2012.

46 Tuba Demirci Yılmaz, "Osmanlı ve Erken Cumhuriyet Dönemi Türkiye Modernleşmesinde Annelik Kurguları", Cogito-Annelik, S. 81, Yaz 2015, s. 79-80.

${ }^{47}$ BOA, DH. UMVM., 166/70, 23 Mayis 1922 (26.09.1340).

${ }^{48}$ Servet-i Fünûn, No:57, s. 68. 
süt ve kan arasında bir bağ kuruluyordu. Bu yüzden çocukların, sütannelerin karakterini, zekâsını, güzelliğini aldıklarına inanılıyordu ve çok titiz davranılıyordu. Hatta hayvan sütüne karşı büyük bir önyargı vardı. Çocukların inek, eşek, keçi, koyun sütüyle beslendiklerinde aptal olabilecekleri düşünülüyordu. ${ }^{49}$ Fakat ilerleyen zamanda öncelik anne sütü, sütanne olsa da zamanla hayvan sütleriyle beslenmeye geçildi. Irzahanede bazı çocuklar sütanneden beslenirken bazıları da inek, eşek veya keçi sütüyle beslenmekteydi. Bebeklerin validesinin veya sütannesinin emzirmesi "rrza tıbbi", bebeklerin inek, eşek ve keçi sütüyle beslenmesine ise "1rza sanayi" denmekteydi. Irza sanayi şişe ile verildiği durumlarda sütün tedariki, saklanması ve ne kadar su katılacağı noktasında oldukça dikkatli olunmak gerekiyordu. Bu nedenle sütün nasıl tedarik edileceği ve saklanacağı meselesi oldukça önemli bir konuydu. ${ }^{50}$

Irzahanenin aşağı katında inek sütlerinin temiz şişelerde hazırlanıp saklandığı ayrıca bir takimhanesi* vardı. Buranın her zaman temiz olması gerekiyordu; çünkü çocukların sağlıklı beslenmesi için burasının sanitasyonu çok önemliydi. Yemek zamanı gelince sütten, memeden kesilmiş çocuklar büyük ve temiz bir sofranın etrafina dizilen küçük koltuk sandalyelerine yerleştiriliyor; tabakları, kaseleri önlerindeki sandalyelere bağlı masalara konuluyor, bakıcı kadınlar herkesin sütlerini, tiridlerini [yemek suyu] doğruca tabağına, kasesine döküyorlardı. Bunu müteakip yemek başlıyordu. Daha küçük olanların gıdaları, sütleri de ihtiyaçlarına göre belirli zamanlarda emziklerle veriliyordu. Fakat çocukların hepsi inek sütüne karşı aynı tepkiyi göstermiyordu. Bünyesi zayıf olan ya da midesinde sıkıntılar olan çocuklara inek sütü zarar verebiliyordu. Bu yüzden irzahane müessesesi bu çocuklar için dört tane dişi sağmal eşek tedarik ederek çocukları bu sütle beslemişlerdi. Üstelik eşeklerin belirli saatlerde ırzahane kapısına getirilip sağılmaları oradaki insanlar için de eğlence unsuru oluyordu. ${ }^{51}$

Irza sanayide tercih edilen öncelikli süt eşek sütüydü. Özellikle ilk iki üç ay bebeklere eşek sütü veriliyordu. Keçi sütü nadiren tercih ediliyordu; fakat bunu da çocuk keçi memesinden kendisi emmeliydi. Eşek sütünün öncelikli olmasının sebebi insan sütüne çok yakın olması ve bebeklerin eşek sütünü iyi hazmetmesiydi. Eşek sütüyle beslenen bebeklerin günden güne kilo aldığı görülmekteydi. Bu da sütün çocuğa yaradığına ve sağlıklı olduğuna işaretti. Avrupa'da çocuklara eşek sütü tedariki için ahırlar mevcutken Osmanlı toplumunda çoğunlukla inek ve keçi sütlerine müracaat olunmaktaydı. Sütünden istifade için şehirlerde hayvan beslemek güç olduğundan, genellikle süt sütçüden alınırdı. Bu halde sütün sağlam ve iyi beslenmekte olan hayvanlardan geldiğine ve safi olduğuna yani hiçbir hileye uğramadığına ve kesilmediğine özen göstermek gerekmekteydi. Ayrıca daima bir terkipte olması için her vakit bir hayvandan sağılan süt tercih olunmalıydı; halbuki sütçüler bir ırktan olmayan muhtelif hayvanlardan sağdıkları sütleri karıştırıp satıyorlardı. Aslında süt tedarik olunduğu yerde tüketilmesi gereken bir üründü. Zira uzak bir mesafeye naklinde sütün tadı değişebiliyordu. Bu yüzden de ırza sanayi, köylerde şehirlerden ziyade iyi sonuçlar veriyordu.

Sütün korunmasına dair dikkat edilmesi gereken hususlardan öncelikli olan gayet serin bir ortamda tutulmasıydı. Bu husus kışın kolay olsa da yazın güçleştiğinden günde iki defa, sabah ve akşam henüz sağılmış taze süt tedarik edilmeliydi. Kaynamamış süt, daha çabuk hazmedildiğinden tercih sebebi ise de çok sıcak zamanlarda kesilip bozulacağından onu hemen kaynatmak gerekiyordu. Kaynamanın diğer faydası da sütte bulunabilecek zararlı mikropları yok etmesidir. Sütü daha sağlıklı saklamak için kaynar su ile kaynatılmış, temizlenmiş çömlek

\footnotetext{
${ }^{49}$ Araz, age, s. 44.; Sütanneliğe dair ayrıntılı bilgi için bkz.; Hürü Sağlam Tekir, "Osmanlı Devleti ve Kültür Coğrafyasında Sütannelik”, Kafkas Üniversitesi Sosyal Bilimler Enstitüsü Dergisi, S. 24, 2019, s. 843-864.

${ }^{50}$ Servet-i Fünûn, No: 57, s. 70.

* Takimhane; 19. yüzyılda sterilizasyon karşılı̆̆ kullanılmış bir kelimedir.

${ }^{51}$ Besim Ömer, age, s. 30-31.
} 
türünden kaplar kullanmak ve bunları ağızlarına kadar doldurup iyice kapattıktan sonra izbe, mahzen gibi serin yerlere bırakmak veyahut serin kuyu suyunun içinde saklamak gerekmekteydi. Ayrıca sütün her defa aynı kaptan alınması hijyen açısından sıkıntı oluşturabileceğinden dolayı bir biberonluk kaplar içinde saklamak daha uygun görülmekte ve her kullanımdan sonra kapların kaynar suda yıkanması öneriliyordu. Sütü kaptan kaba dökmek de iyi değildi; çünkü sütün bu şekilde kesilmesi kolaylaştığından böyle bir süt kesinlikle çocuğa verilmemeliydi. ${ }^{52}$

Anne sütünden ya da sütnineden mahrum çocuklar için hayvan sütü kullanılması durumunda dikkat edilecek başka bir husus da sütün sulandırılması meselesiydi. İnek sütü insan sütünden daha koyu olduğu için çocuklarda hazım sorununa sebep olacağından dolayı hekimler su katılmasını tavsiye ediyorlardı. Su katıldığı için şeker ilavesi de yapılıyordu; çünkü su katılan sütün şeker oranının azaldığı düşünülüyordu. Su ve şekerin ne ölçüde katılacağına dair Besim Ömer'in de öğrencisi olduğu Mösyö Budin, ilk haftalarda su oranının daha fazla olmasına dikkat çekerken, ilerleyen aylarda süt oranının fazlalaştığına dikkat çekmektedir. Öte yandan çocuğun sağlık durumuna göre suyun oranı azaltılıp çoğaltılabilirdi. Doktorlar tarafından tartışılan bir husus da süte katılacak olan suyun saf su mu yoksa mineralli su mu katılacağı meselesiydi. Birçok doktor suya pişirilmiş arpa, ekmek suyu katılmasını tavsiye ediyordu. ${ }^{53}$ Fakat Budin sütün kesilebileceği ihtimalinden ötürü saf su konulmasını önermekteydi. Bu şekil beslenmede bebekte hazımsızlık ve kabızlık durumu gelişirse çocuğun sütüne hazımsızlıkta birkaç tuz tanesi, kabızlıkta 5 cgr karbonat tozu ilave edilmeliydi.

Süte karıştırılacak şeker konusunda ise doktorların fikri; inek sütüne ilave olunacak 1.000 gram suya 50 gram şeker ya da 100 gram suya 5 gram şeker konulmasıydı. Bu şekilde inek sütü insan sütü gibi olacaktı. Bununla birlikte bazı çocuklar şekeri güç hazmettikleri için süt şekeri (laktoz) tedarik etmek daha anlamlı olacaktı. İnek sütüyle kıyaslandığında keçi sütüne daha az şeker ve aynı miktarda su konulması; koyun sütüne ise bir buçuk katı su ve biraz daha fazla şeker ilave edilmeliydi. Eşek ve kısrak sütlerine ise çeyrek su ilave edilmeliydi. ${ }^{54}$

Bebeklere verilecek sütün 1sısı henüz memeden çıkan süt kadar yani 37 derecede olmalıydı. Bunu süt şişesini kaynar suya koyarak ya da süte sıcak su katarak ayarlamak mümkündü. Süt bebeğe tas, kâse, bardak, kaşık ve emzik şişeleri ile verilebilirdi. Nitekim bardak, kâse ve kaşı̆̆ın temizlenmesi kolay olmakla birlikte çocuğun bunlarla süt içerken hava yutması çok sağlıklı olmayabilirdi. Biberonların tehlikeli yönü ise tamamen temizlenmelerinin pek kolay olmamasiydi.

Irzahanede bebeklerin beslenme süreleri de hassasiyetle yapılıyordu. Aylık gelişimlerine göre bu süre değişebiliyordu. Mesela üçüncü aya kadar gündüz her iki saatte bir meme, gece her dört saatte bir meme; üçüncü aydan 6 . aya kadar gündüz her 3 saatte bir defa, gece her 6 saatte bir defa; 6 . aydan 12. aya kadar gündüz her 3 saatte bir meme, gece yalnız bir meme vermek ve hatta yavaş yavaş memeyi kesmek gerekiyordu. 12. aydan 18. aya kadar gündüz her 3 saatte bir meme, iki üç defa da ağlamasına göre süt verilebilirdi. Bu aydan sonra geceleri bebek memeden tamamen kesilmeliydi. ${ }^{55}$

Çocuğa annesi süt veremediği takdirde uygun bir sütnine bulup 1rzahanede bebeği besleyebiliyordu. Eğer bu mümkün değilse üç ay halis eşek sütü ve sonra da inek sütü veriliyordu.

52 Servet-i Fünûn, No: 57, s. 70.

${ }^{53}$ Servet-i Fünûn, No: 57, s. 70.

${ }^{54}$ Servet-i Fünûn, No: 57, s. 71.

55 Servet-i Fünûn, No: 57, s. 71. 
Şayet eşek sütünün tedariki yapılamazsa ilk ayda verilecek olan inek sütünün daha önce de bahsedildiği şekilde su ile karıştırılarak verilmesi uygundu. ${ }^{56}$

Anne sütünden mahrum olan çocuklar bir dönem gazetelerin son sayfalarındaki ilanlarda adı geçen unlarla beslenmişlerdi. Bu ebeveynlerin çoğunlukla evlat acısıyla sınandıkları vakalar olmuştu. Kadri Râşit makalesinde bu konuya dikkat çekerek Tıp Fakültesi'nde çocuk kliniği dersinde muayenehaneye getirilen çocukların hastalıklarında bu ilanların etkisini fazlasıyla gördüğünden bahsetmiştir. Bu hazır mamaları "çocuk katili" diye niteliyordu; çünkü birçok çocuk bu mamalar yüzünden zehirlenmiş, şiddetli çocuk koleralarına yakalanmış, acılar içerisinde can vermişlerdi. Öte yandan bir kısmı da havale hastalığından ötürü kıvrıla kıvrıla, gerile gerile ölmüş ya da bacakları eğrilmiş, karınları şişmiş ve sırtları kamburlaşarak hayatları felakete dönüşmüştür. ${ }^{57}$

1900'lü yıllara bakıldığında çoğu ülkede ölümlerin büyük bir oranını çocuk ölümlerinin oluşturduğu görülmektedir. Bu ölümlerin çoğu da mide hastalıklarından ileri geliyordu. İtalya'da 1902 yılında sıfır ve otuz altı ay arasında olan 267.775 çocuk ölmüştü. Bunlar arasında sadece mide hastalıklarından dolayı ölen çocukların sayısı ise $62.365^{\prime}$ tir. Özenli bir şekilde araştırmalar yapıldığında ölümlerin mide ve bağırsak özelinde olduğu ve bunun da dikkatsizlik ve bilgisizlik sonucu ortaya çıtı̆̆ gözlemlenebilir. Nitekim bu da ebeveynlerin eğitimi ve bilgilendirilmeleriyle engel olunabilir bir sorun olarak gözükmekteydi. ${ }^{58}$

\section{Irzahanenin Karanlık Yüzü: Çocuk Ölümleri}

Cumhuriyet döneminde "Darülaceze Çocuk Yuvası" ismini alan ırzahaneye 27 senelik süreçte yani açıldığı yıl olan 1903'ten 1930 yılına kadar 4.685 çocuk alınmış olup bunların 1.495 'i evlatlık ya da velilerine verilmiş, 2.360 '` ölmüş geriye 730 çocuk kurumda kalmıştır. ${ }^{59}$

\begin{tabular}{|l|l|}
\hline Dönem & Nevzad $^{*}$ \\
\hline $\begin{array}{l}\text { 17 Temmuz 1903'ten 13 Mart 1916'ya } \\
\text { kadar duhul }\end{array}$ & 932 \\
\hline $\begin{array}{l}\text { 17 Temmuz 1903'ten 13 Mart 1916'ya } \\
\text { kadar çıkan }\end{array}$ & 300 \\
\hline $\begin{array}{l}\text { 17 Temmuz 1903'ten 13 Mart 1916'ya } \\
\text { kadar vefat eden }\end{array}$ & 572 \\
\hline Eytamhaneye Devredilen & 18 \\
\hline Kalan & 42 \\
\hline
\end{tabular}

Tablo 1: 17 Temmuz 1903’ten 13 Mart 1916’ya kadar Irzahane İstatistiği ${ }^{60}$

Arşiv belgelerine yansıyan ırzahane istatistiğinin müessesenin açıldığı 1903 yılından 1916 yılına kadar vermiş olduğu rakamlar sağlıklı bir değerlendirmede bulunma imkânı sunmaktadır. On üç yıllık süreç göz önüne alındığında 1rzahaneye giren 932 çocuğun 572'sinin hayatını kaybettiği görülmektedir. Yani \%61,37 gibi oldukça yüksek bir ölüm oranına sahiptir.

${ }^{56}$ Servet-i Fünûn, No: 57, s. 71-72.

${ }^{57}$ Kadri Râşit, agm, s. 59.

${ }^{58}$ Kadri Râşit, agm, s. 55-56.

${ }^{59}$ Ali Suat, "Darülaceze ve Dilenciler Hakkında", Istanbul Şehremaneti Mecmuası, Temmuz-Ağustos 1930, Y11 6, S. 71-72, s. 428.

*Yeni doğmuş çocuk-bebek.

${ }^{60}$ BOA, DH. UMVM., 113/58, 13 Kasim 1920 (01.03.1339). 
Cumhuriyet idaresine devredilene kadar yüksek ölüm oranlarının önüne bir türlü geçilememiştir. ${ }^{61}$

\begin{tabular}{|l|l|}
\hline Dönem & Nevzad \\
\hline Mart 1916'da Devreden & 42 \\
\hline 1916'da duhul eden & 180 \\
\hline 1916'da ç1kan & 42 \\
\hline 1916'da vefat eden & 111 \\
\hline Eytamhaneye Devredilen & 12 \\
\hline Kalan & 57 \\
\hline
\end{tabular}

Tablo 2: Mart 1916 Yılındaki Irzahane İstatistiği ${ }^{62}$

\begin{tabular}{|l|l|}
\hline Dönem & Nevzad \\
\hline $\begin{array}{l}\text { Mart 1917 başında } \\
\text { devreden }\end{array}$ & 57 \\
\hline 1917'de duhul eden & 251 \\
\hline 1917'de çıkan & 47 \\
\hline 1917'de vefat eden & 201 \\
\hline $\begin{array}{l}\text { Eytamhaneye } \\
\text { Devredilen }\end{array}$ & 22 \\
\hline Kalan & 38 \\
\hline
\end{tabular}

Tablo 3: Mart 1917 Yılındaki Irzahane İstatistiği ${ }^{63}$

\begin{tabular}{|l|l|}
\hline Dönem & Nevzad \\
\hline $\begin{array}{l}\text { Mart 1918 başında } \\
\text { devreden }\end{array}$ & 38 \\
\hline 1918'de duhul eden & 250 \\
\hline 1918'de çıkan & 29 \\
\hline 1918'de vefat eden & 216 \\
\hline $\begin{array}{l}\text { Eytamhaneye } \\
\text { Devredilen }\end{array}$ & 9 \\
\hline Kalan & 33 \\
\hline
\end{tabular}

Tablo 4: Mart 1918 Yılındaki Irzahane İstatistiği ${ }^{64}$

\begin{tabular}{|l|l|}
\hline Dönem & Nevzad \\
\hline
\end{tabular}

${ }^{61}$ BOA, DH. UMVM., 113/58, 13 Kasim 1920 (01.03.1339).

${ }^{62}$ BOA, DH. UMVM., 113/58, 13 Kasim 1920 (01.03.1339).

${ }^{63}$ BOA, DH. UMVM., 113/58, 13 Kasim 1920 (01.03.1339).

${ }^{64}$ BOA, DH. UMVM., 113/58, 13 Kasim 1920 (01.03.1339). 


\begin{tabular}{|l|l|}
\hline $\begin{array}{l}\text { Mart } 1919 \text { başında } \\
\text { devreden }\end{array}$ & 33 \\
\hline 1919'da duhul eden & 218 \\
\hline 1919'da ç1kan & 32 \\
\hline 1919'da vefat eden & 184 \\
\hline $\begin{array}{l}\text { Eytamhaneye } \\
\text { Devredilen }\end{array}$ & 3 \\
\hline Kalan & 32 \\
\hline
\end{tabular}

Tablo 5: Mart 1919 Yılındaki Irzahane İstatistiği ${ }^{65}$

Yukarıda görülen dört tablo ayrıca Birinci Dünya Savaşı yıllarını göstermesi açısından önem arz etmektedir. Osmanlı Devleti'nin birçok cephede savaşmak zorunda kaldığı, yıpratıcı ve uzun savaş yılları ekonomiden sosyal hayata kadar birçok alanı derinden etkilemiştir. Gelişen silah teknolojileri cephe gerisini de doğrudan etkilediğinden çok sayıda insan evlerini ve yurtlarını terk etmek zorunda kalmıştır. ${ }^{66}$ Doğu Anadolu ve Doğu Karadeniz'de işgal edilen bölgelerden bir milyondan fazla insan Batı bölgelerine göç etmek zorunda kaldı. Bu bağlamda 1rzahaneye gelen çocuk sayısının artmasındaki en önemli etmenlerin savaş, yoksulluk ve göçler olduğu söylenebilir. Bunun yanında savaş öncesi yılların da en büyük sorunu olan çocuk ölümlerinin önüne savaş yıllarında da geçilemediği görülmektedir. Mondros Mütarekesi'ni takip eden 1919 yılında da ölüm oranları oldukça yüksektir.

\begin{tabular}{|l|l|l|l|}
\hline Gelen & Çıkan & Vefat & Açıklama \\
\hline 684 & 226 & 456 & 1903'ten 1913 sonuna kadar \\
\hline 1.147 & 225 & 828 & 1914'ten 1919 sonuna kadar \\
\hline 185 & 37 & 142 & 1 Ocak 1920'den 20 Eylül 1920'ye kadar \\
\hline Yekûn & Yekûn & Yekûn & \\
\hline 2.016 & 488 & 1.426 & \\
\hline
\end{tabular}

Tablo 6: 1903-1920 Irzahane İstatistiği ${ }^{67}$

\begin{tabular}{|l|l|}
\hline Ícmal & Yek̂̂n \\
\hline $\begin{array}{l}\text { 19 Temmuz 1903'ten-30 Eylül } \\
\text { 1920'ye kadar gelen }\end{array}$ & 2.077 \\
\hline $\begin{array}{l}\text { 19 Temmuz 1903'ten-30 Eylül } \\
\text { 1920'ye kadar çıan }\end{array}$ & 488 \\
\hline $\begin{array}{l}\text { 19 Temmuz 1903'ten-30 Eylül } \\
\text { 1920'ye kadar vefat eden }\end{array}$ & 1.426 \\
\hline Eytamhaneye Devredilen & 64 \\
\hline 1 Eylül 1920 İtibariyle Mevcudu & 29 \\
\hline
\end{tabular}

Tablo 7: 1903-1920 Irzahane İstatistiği ${ }^{68}$

${ }^{65}$ BOA, DH. UMVM., 113/58, 13 Kasım 1920 (01.03.1339).

${ }^{66}$ Birinci Dünya Savaşı'ndaki göçlerle ilgili ayrıntılı bilgi için bkz.; Süleyman Tekir, 'Birinci Dünya Savaşı'nda Doğu Anadolu ve Doğu Karadeniz Rus İşgal Bölgelerinden Yapılan Göçler”, Çağdaş Türkiye Tarihi Araştırmaları Dergisi, 16/32, 2016 Bahar, s. 43-64.

${ }^{67}$ BOA, DH. UMVM., 113/58, 13 Kasim 1920 (01.03.1339).

${ }^{68}$ BOA, DH. UMVM., 113/58, 13 Kasim 1920 (01.03.1339). 
Tablo 6 ve 7 incelendiğinde 1rzahanenin yıllar içerisindeki genel panoraması görülmektedir. Genel duruma bakıldığında kurulduğu günden itibaren çocuk ölümlerinin her ne şekilde tedbirler alınırsa alınsın önlenemeyen kayıpların olduğu görülmektedir. 1914-1919 yılları arasında ırzahaneye gelen çocuk sayısının diğer yıllara kıyasla oldukça arttığı anlaşılmaktadır. Bununla birlikte çocuk ölümleri hem sayısal hem de oransal (\%72) olarak ciddi boyutlara ulaşmıştır.

Tablolara da yansıdığı üzere ırzahane kurulduğu günden itibaren çözülemeyen en büyük sorun hiç şüphesiz ki çocuk ölümleriydi. 1921-1922 döneminde \%75-80 gibi oldukça yüksek -ki her on çocuktan sekizi hayatını kaybediyordu- oranlara yükselmişti. Mülkiye müfettişleri tarafindan sekiz ay boyunca yapılan tahkikat neticesinde ulaşılan ilk bulgular şu şekildeydi: sekiz ay boyunca devam eden tahkikat ve tetkikat esnasında 1rzahanede tek bir hekime dahi tesadüf edilmemişti. Eski müdür Zühdü Bey’in idaresi zamanında 1rzahane tabibi olarak görev yapan Şükrü Bey izinli olarak Almanya' ya gönderilmişti. Hali hazırdaki yönetim zamanında bir müddet istihdam edilen İslam Bey, rapor hazırlandığı dönemde İstanbul Sihhiye Müdürü olmuştu. Muhacirin Müdüriyeti Umumisi Sihhiye Müdürü Vekaleti Emraz-1 Sariye Tababeti daha başka hizmet ile meşgul olduğundan ırzahane ile iştigale vakit bulamıordu. Halen 1rzahane tabibi olan Emin Bey de vazifesine devam ediyordu. Fakat birer birer hayatlarını kaybeden biçare çocukların sağlıklarına kavuşmaları için ırzahaneye acilen çocuk hastalıklarında uzman bir hekimin gönderilmesi gerekiyordu. Öte yandan ırzahanede istihdam edilen sütannelerin sayılarının yetersizliğine rağmen her birine kendi çocuğundan başka iki, hatta daha çok çocuk tevdi ediliyordu. Sorunların kısa sürede önüne geçilebilmesi için acilen beş sütannenin daha işe alınması gerekiyordu. ${ }^{69}$ Osmanlı Devleti'nin fiilen sona erdiği bu tarihlerde tüm şehirlerde olduğu gibi Darülaceze'de de çok ciddi sıkıntılar ortaya çıkmıştı.

Darülaceze'nin, Cemiyeti Umumiye Belediye Tetkiki Hesap Encümeni tarafindan yapılan 1928 yılı raporundaki bir cetvel, 27 senelik bir çocuk yuvası istatistiğini vermesi açısından önemlidir. Bu cetvelde müesseseye giren evlatlık veya ebeveynine teslim edilen ve ölen çocuk sayısı senelere göre belirtilmiştir. İlk yıl yani 1903'te 17 çocuk varken 1929 yılında 168 'i erkek ve 173 'ü kız olmak üzere 341 çocuk bulunmaktaydı. Hazırlanan cetvelde çocukların yaş1 gösterilmemiştir; fakat $\% 35, \% 40$ ve hatta $\% 80$ gibi ölüm yüzdelik oranları verilmiştir. Ayrıca $\% 20$ 'sinin doğum anında ve vaktinden önce doğduğu için öldügü de belirtilmiştir. ${ }^{70}$

Darülaceze 1rzahanesinin açılış tarihi olan 22 Nisan 1903'ten 1 Mayıs 1920 senesine kadar ırzahaneye gelen, vefat eden ve hayatta kalan çocukların gösterildiği aşağıdaki tablo çocukların aylık durumlarına dair daha detaylı bilgiler içermektedir. ${ }^{71}$

\begin{tabular}{|c|c|c|c|c|c|c|c|c|c|c|c|c|}
\hline \multirow[t]{2}{*}{ Tarih } & \multicolumn{3}{|l|}{ Duhul } & \multicolumn{3}{|l|}{ Vefat } & \multicolumn{3}{|c|}{ Hayatta Kalan } & \multirow{2}{*}{$\begin{array}{l}\text { Duhul } \\
\text { Yekûnu }\end{array}$} & \multirow{2}{*}{$\begin{array}{l}\text { Vefat } \\
\text { Edenlerin } \\
\text { Yekûnu }\end{array}$} & \multirow{2}{*}{$\begin{array}{l}\text { Hayatta } \\
\text { Kalanların } \\
\text { Yekûnu }\end{array}$} \\
\hline & $\begin{array}{l}1-6 \\
\text { Aylık }\end{array}$ & $\begin{array}{l}6 \\
\text { Ay- } \\
1 \\
\text { Yaş }\end{array}$ & $\begin{array}{l}1-3 \\
\text { Yaş }\end{array}$ & $\begin{array}{l}6 \text { Ay- } \\
1 \text { Yaş }\end{array}$ & $\begin{array}{l}1-6 \\
\text { Aylık }\end{array}$ & $\begin{array}{l}1-3 \\
\text { Yaş }\end{array}$ & $\begin{array}{l}1-6 \\
\text { Aylık }\end{array}$ & $\begin{array}{l}6 \text { Ay- } \\
1 \text { Yaş }\end{array}$ & $\begin{array}{l}1-3 \\
\text { Yaş }\end{array}$ & & & \\
\hline $\begin{array}{l}1903- \\
1915\end{array}$ & 672 & 171 & 89 & 62 & 500 & 10 & 172 & 109 & 79 & 932 & 572 & 360 \\
\hline $\begin{array}{l}1915- \\
1916\end{array}$ & 153 & 17 & 11 & 10 & 100 & 1 & 52 & 7 & 10 & 181 & 111 & 70 \\
\hline $\begin{array}{l}1916- \\
1917\end{array}$ & 180 & 34 & 37 & 20 & 171 & 10 & 9 & 14 & 27 & 251 & 201 & 50 \\
\hline
\end{tabular}

${ }^{69}$ BOA, DH. UMVM., 119/23, 11 Ocak 1922 (12.05.1340).

${ }^{70}$ Ali Suat, agm, s. 428.

${ }^{71}$ BOA, DH. UMVM., 114/44, 24 Kasım 1921 (23.03.1340). 
Osmanlıda Kimsesiz ve Yoksul Çocuklara Anne Şefkati: Irzahane

\begin{tabular}{|l|l|l|l|l|l|l|l|l|l|l|l|l|}
\hline $\begin{array}{l}1917- \\
1918\end{array}$ & 221 & 21 & 8 & 14 & 200 & 2 & 21 & 7 & 6 & 250 & 216 & 34 \\
\hline $\begin{array}{l}1918- \\
1919\end{array}$ & 166 & 42 & 10 & 27 & 155 & 2 & 11 & 15 & 8 & 218 & 184 & 34 \\
\hline $\begin{array}{l}1919- \\
1920\end{array}$ & 143 & 49 & 28 & 37 & 110 & 14 & 28 & 12 & 14 & 220 & 161 & 54 \\
\hline Yekûn & 1.535 & 334 & 183 & 170 & 1.236 & 39 & 293 & 164 & 144 & 2.052 & 1.445 & 602 \\
\hline
\end{tabular}

Tablo 8: 1903-1920 Ayrıntılı Irzahane İstatistiğ ${ }^{72}$

Irzahane kayıtları incelendiğinde bebek ölüm oranlarının daha önceki tablolarda bahsettiğimiz gibi oldukça yüksek olduğu dikkat çekmektedir. Tablo 8'de görüldüğü üzere ırzahaneye kayıtlı olan bebeklerin yaş aralıklarına ilişkin daha detaylı bilgiler yer almaktadır. Bu veriler incelendiğinde özellikle 1-6 aylık bebeklerin ölüm oranlarının oldukça yüksek olduğu göze çarpan en önemli husustur. Örneğin 1903-1915 yılları arsında 1rzahanedeki 1-6 aylık bebek ölüm oranı \%74,46 gibi oldukça yüksek bir orandır. Yine aynı yıllar içerisinde 6 ay-1 yaş arası bebeklerin ölüm oranı \%36,25, 1-3 yaş arası bebeklerin ölüm oranı ise $\% 11,23$ olarak kayda geçmiştir. Burada bebeklerin ayları düştükçe ölüm oranlarının yükselmesinin nedenini daha küçük aylardaki bebeklerin süte daha bağlı bir beslenme tarzına sahip olmalarıyla açıklanabilir.

Irzahanedeki çocuklar arasında ölüm oranlarının oldukça yüksek olması üzerine sıhhiye müdiriyeti umumiyesi tarafından görevlendirilen teftiş heyeti hazırladığı raporda bu konuda ciddi tespitler yapmıştı. Rapora göre 1913-1920 yılları arasında 1rzahaneye getirilen 1 aylıktan 3 yaşına kadar çocukların toplamı 2.052 iken bunlardan 1.445 'i vefat etmişti. Ölüm oranı \% 70 gibi kabul edilemez seviyelerdeydi. Ölümlerin altında yatan sebepler ise oldukça çarpıcıydı. Vefat edenlerin çoğunluğu polis tarafindan sağda solda metruk binalarda bulunup Darülaceze'ye sevk edilen kimsesiz çocuklardı. Polis tarafından bulunup Darülaceze'ye sevk edilene kadar geçen sürede uzayan bürokratik işlemler çocukların çok sayıda harici tesire maruz kalmalarına sebep oluyordu. Yedi senelik süre içerisinde bürokratik işlemlerin (evrak, tebligat vb.) olumsuz tesirlerinin farkına varılarak gerekli düzenlemeler yapılmasına rağmen çocuk ölüm oranlarında fark edilebilir bir düşüş görülmemişti. Diğer yandan çocukların temizliği ve özel sağlık durumlarına gerektiği kadar ihtimam gösterilmemesi cahil, batıl inanç sahibi, tembel birtakım kadınların ellerine bırakılmış olmaları ölüm oranlarının en önemli sebeplerinden biri olarak göze çarpıyordu. Bunun yanında rzahaneden sorumlu olan doktor üç aydan beri izinli olarak Avrupa'da bulunurken önceki süreçte de çeşitli vesilelerle izinli olduğu tespit edilmiştir. Konunun uzmanı izinli olduğu için Darülaceze'nin erkek ve kadın düşkünlerine mahsus hastanesinin iki tabibi tarafından imkân dahilinde çalışıldığı görülmektedir. Erkek ve kadınlara mahsus hastanenin teftişinde ise bağırsak iltihabı hastalarının yoğun olarak bulunduğu, hastaların ateşlerini gösteren kâğıtların olmadığı, bulaşıcı cilt hastalığı taşıyan hastaların tecrit edildiği hastane idaresinin yetersiz olduğu anlaşılmıştı. Tüm bunların düzeltilebilmesi için acilen konunun uzmanı bir tabibin 1rzahaneye görevlendirilmesi gerekmekteydi. Irzahanedeki çocukların, temizlik, emzirme, düzen gibi sıhhi hususları mütehassıs tabip hatta baştabip tarafından pek sıkı şekilde denetlenmeliydi. Çocuklar vazifeşinas, şefkatli, talim terbiye görmüş bakıcı ve dadılara teslim edilirse vefat sebebinin en önemli amili olan bakımsızlığa son verilebilirdi. Aylık olarak düzenlenecek vefat ve sebepli vefat cetvelleri S1hhiye Müdüriyet-i Umumiyesine kesinlikle teslim edilecekti. ${ }^{73}$

Müessesenin üst katlarına Terkos suyunun ulaşmaması nedeniyle genel temizlik icra olunamıyordu. Yeterli miktarda su tedarikinin çaresi ve abdesthanelerle, lağımların yanlış yerlere

${ }^{72}$ BOA, DH. UMVM., 114/44, 24 Kasim 1921 (23.03.1340).

${ }^{73}$ BOA, DH. UMVM., 114/44, 24 Kasım 1921 (23.03.1340). 
inşa edilmesi binalardaki kötü kokunun asıl sebebiydi. Bu durum başlı başına ahval-i sıhhiyeyi tehdit ediyordu. Sıhhiye Nazırı adına Sihhiye Müdürü Umumisi Abdullah Cevdet Bey tarafından Eylül 1921'de hazırlanan rapor irzahanenin içerisinde bulunduğu durumu tüm çıplaklığı ile ortaya koyuyordu. ${ }^{74}$ Nitekim çalışmanın başında bahsettiğimiz ırzahanenin fiziksel yeterliliğine dair bilgiler burada soru işaretleri olarak karşımıza çıkmaktadır.

Irzahanede hayatta kalmayı başarabilen/şanslı olan çocuklar, münasip görüldüğü takdirde evlatlık isteyenlere veriliyordu. Fakat evlatlık alacakların çocuklara ne suretle baktığı ve çocukların genel durumlarının sıklıkla kontrol edilmeleri şartıyla evlatlık işlemlerinin yapılması uygun görülmekteydi. ${ }^{75}$ İslamiyet'e kadar birçok din ve kültürde evlat edinme/evlatlık alma uygulaması var olmasına rağmen İslamiyet'le birlikte bu uygulama kaldırılmıştır. Ancak İslam ve özellikle Türk hukuk tarihinde evlatlık kurumu zaman zaman koruyucu aile tarzında varlığını sürdürmüştür. ${ }^{76}$ Bununla birlikte Darülaceze'nin I. Dünya Savaş1 ve takip eden süreçte ülkenin mali açıdan zor bir sürece girmesi üzerine kurallara uygun olmadığı halde kalmalarına izin verilen acizlerin kurumdan çıkarılması, şayet bakacakları kimseleri varsa yanlarına gönderilmeleri, kimsesiz çocukların da varsa akrabalarına veya evlat edinme suretiyle isteyen ailelere teslim edilmesi gündeme geldi. İslam Hukuku ile bağdaşmamasına rağmen mali zorluklar ve devam eden savaş sebebiyle Ağustos 1920'de Darüleytamdaki kız çocuklarının "erbab-1 namus ailelere" evlatlık verilmesi, erkek çocuklarının ise esnafların yanına çırak olarak verilmesine meclis-i vükela tarafından karar verildi. ${ }^{77} 1906-1915$ döneminde 31 erkek, 52 k1z olmak üzere toplamda 83 çocuk evlad-1 manevi suretiyle ailelere verilirken; 1916-1921 döneminde 54'ü erkek, 88'i kız olmak üzere 142 çocuk evlatlık olarak ailelere verildi. Evlatlık verme uygulamasının başladığı 1906 yılında bir erkek ve bir kız çocuğunun verilmesi ile başlayan uygulamanın her geçen yıl katlanarak arttığı görülmektedir. ${ }^{78}$

Volume 12 Issue 6

December 2020

Dahiliye Nezareti Temmuz 1921'de Darülaceze Müdüriyeti 'ne yazdığı yazıda kurumdan çıkarılacak çocukların tekrardan sokaklarda sürünmemesi için evlatlık veya hizmetli isteyenlere senet karşılığında verilmelerini bildiriyordu. Bu kişilerin hakkında tahkikat yapılıp maddi durumlarının elverişli olup olmadığı ve kefalet aranması hususlarına özen gösterilmeliydi. Bu uygulamanın genellikle Darüleytam 'da kalan yetimler için uygulandığı görülmekle birlikte henüz süt çağında olan çocuklar için de uygulandığı belgelerden anlaşılmaktadır. ${ }^{79}$

\section{Sonuç}

19. yüzyılın ikinci yarısından itibaren kimsesiz ve yetim çocuklar için devlet, kurumsal çözüm yolları üretmeye başlamıştı. Sosyal devlet olgusuyla II. Abdülhamid döneminde Darülaceze'nin açılması da bu bağlamda değerlendirilebilir. Darülaceze içerisinde çok sayıda hizmet birimini barındırmaktaydı; bunlardan bir tanesi de ırzahaneydi. Irzahane yeni doğmuş kimsesiz ve yoksul çocuklara kucağını açan bir şefkat yuvasıydı. Aileleri tarafından terk edilen, sokaklarda biçare kalmış çocukların durumuna ancak devlet eliyle çözüm bulunabilirdi. Çocukların ölüm oranlarındaki artış, kimsesiz ve sokakta yokluk içinde yaşayan çocukların her köşede feryat etmeleri sosyal devlet olgusuyla çelişen bir durumdu. Irzahanenin açılması tüm bunlar için adeta planlanmış bir çare oldu.

Irzahanenin açıldığı dönemin kendine özgü koşulları gereği İstanbul'da sosyal ve ekonomik hayat bir çıkmazın içerisindeydi. Fakat masumiyetin sembolü olarak düşünebileceğimiz

${ }^{74}$ BOA, DH. UMVM., 114/44, 24 Kasım 1921 (23.03.1340).

${ }^{75}$ BOA, Zaptiye Nezareti Evrakı (ZB.), 329/106, 14 Ocak 1909 (R. 01.11.1324).

${ }^{76}$ Mehmet Âkif Aydın, "Evlât Edinme", Türkiye Diyanet Vakfi İslam Ansiklopedisi, C. 11, İstanbul 1995, s. 527-529.

${ }_{77}$ BOA, Meclis-i Vükela Mazbatalarl (MV.), 220/85, 12 Eylül 1920 (28.12.1338).

${ }^{78}$ BOA, DH. UMVM., 113/71, 28 Temmuz 1921 (22.11.1339).

${ }^{79}$ BOA, DH. UMVM., 119/19, 19 Aralık 1921 (18.04.1340). 
çocukların da en iyi şartlarda bakılmaya ve yetiştirilmeye hakları vardı. Bu bakımdan ırzahane döneminin modern bir kurumu olarak düşünülebilir. Dönemin yayınlarında ırzahanede kullanılan araç gereçler, beslenme, çocuklara gösterilen hassasiyet gibi konuların propagandası yapılsa da arşiv belgelerinden anlaşılan çocuk ölümlerinin önüne geçilemediğidir. Nitekim 1rzahane binasında Avrupa'daki örnekler göz önüne alınarak bebek ve çocuklar için elverişli bir ortam hazırlanmıştı; fakat istenen sonuç bir türlü alınamamıştır. 1-6 aylık bebekler arasındaki ölüm oranlarının çok yüksek olması bunun en büyük göstergesidir. Yıllar bazında ele alındığında 1-6 aylık bebeklerin ırzahaneye yoğun olarak getirildikleri tarihlerde ölüm oranları aynı doğrultuda artış göstermiştir. Çünkü bu ay aralığındaki bebekler daha çok anne sütüne muhtaçtı. Öte yandan sıkıntılı bir durum da ırzahane bünyesinde istihdam edilen sütannelerin sayılarının yetersizliği meselesiydi. Sütannelere kendi çocuğundan başka iki, hatta daha çok çocuk veriliyor olması çocuk beslenmesini oldukça olumsuz etkilediğinden dolayı ölümlerin önüne geçilememiştir.

1903 yılında böyle bir müessesenin açılmasıyla birlikte Osmanlı Devleti'nde kadınlar da evlerinin dışında bir çalışma ortamı, para kazanabilme imkânı bulmuşlardır. Irzahanedeki bebeklere sütannelik, dadılık gibi birtakım görevleri üstlenen kadınlar hem maddi gelir sağlamışlar hem de kendi çocuklarını kaybeden sütanneler bu vesileyle annelik duygularını bir nebze de olsa yaşayabilmişlerdir.

Emzirme, aynı zamanda çocuğa dokunmak, çocuğu sevmek gibi de düşünülebilir. Sevilen ve daha fazla vakit geçirilen çocukların sağlıklı ve büyümeye daha yatkın olduğu bilgisinden yola çıkılarak sütannelere sahip olan/sütannesini daha az çocukla paylaşan 1-6 aylık çocukların hayatta kalma şanslarının daha yüksek olacağı çıkarımında bulunulabilir. Irzahanedeki bu yaş grubu çocuklardaki ölüm oranlarının yüksek olması bu savı doğrulayan en önemli kanıttır.

II. Abdülhamid döneminin bütününe bakıldığında Padişah'ın kadın, çocuk, kimsesizlere yönelik gerçekleştirmiş olduğu faaliyetler de göz önüne alınarak çocukların sağlığının Padişah'ın siyasi söyleminde ayrı bir yeri olduğu söylenebilir. Ayrıca dünyada çocuk sorununa artan ilginin, II. Abdülhamid döneminde nasıl bir şekil kazandığına dair fikir vermesi açısından da bu çalışma dikkate değerdir.

\section{Kaynakça}

\section{Arşivler}

Türkiye Cumhuriyeti Cumhurbaşkanlığı Devlet Arşivleri Başkanlığı Osmanlı Arşivi (BOA), Dahiliye Nezâreti Mektubî Kalemi (DH.MKT.), 727/40; 1022/26.

Umûr-ı Mahalliyye-i Vilayât Müdürlüğü (DH.UMVM.), 113/27; 156/102; 165/5; 165/38; 149/46; 166/70; 113/58; 119/23; 114/44; 113/71; 119/19.

Zaptiye Nezareti Evrakı (ZB.), 329/106.

Meclis-i Vükela Mazbataları (MV.), 220/85.

\section{Gazete ve Dergiler}

Akşam Gazetesi

Servet-i Fünûn Dergisi

İstanbul Şehremaneti Mecmuası

Şehremaneti Mecmuası

\section{Resmî Yayınlar}


Darülaceze Talimatnamesi, Ahmed İhsan ve Şürekası Matbaacılık Osmanlı Şirketi, İstanbul 1329.

\section{Telif ve Tetkik Eserler}

Ali Suat, "Darülaceze ve Dilenciler Hakkında", Şehremaneti Mecmuası, Temmuz-Ağustos 1930, Y1l 6, S. 71-72.

ARAZ, Yahya, 16. Yüzyıldan 19. Yüzyıl Başlarına Osmanlı Toplumunda Çocuk Olmak, Kitap Yayınevi, İstanbul 2013.

AYDIN, Mehmet Âkif, "Evlât Edinme", Türkiye Diyanet Vakfi İslam Ansiklopedisi, C. 11, İstanbul 1995, s. 527-529.

Besim Ömer, Darülaceze Irzahanesi, Ahmed İhsan ve Şürekası Matbaası, İstanbul 1319.

Ehâsin-i Müessesât-1 Hayriye-i Hazret-i Hilâfet-penahîden Darülaceze, Mihran Matbaası, İstanbul 1324.

GÜNDÜZ, Ahmet, “Osmanlı'da Kimsesiz Çocukların Himaye ve Korunması: Antakya Örneği (1860-1900)", Geçmişten Günümüze Şehir ve Çocuk II, Ed. Osman Köse, Canik Belediyesi Kültür Yayınları, Samsun 2016, s. 789-796.

İstanbul Şehremaneti Mecmuasl, 30 Teşrinîsânî 1341/30 Kasım 1925, C. 2, S.16, s. 108-110.

KÖSE, Saffet, "Lakit”, Türkiye Diyanet Vakf İslam Ansiklopedisi, C. 27, Ankara 2003, s. 68-69.

MÜEZZINNOĞLU, Ersin, "I. Dünya Savaşı Esnasında Yetim ve Öksüz Çocukların Himayesi ve Eğitimi: Darüleytamlar”, History Studies, 4/1, 2012, s. 399-417.

NUHOĞLU, Hidayet Y., "Dârülaceze”, Türkiye Diyanet Vakfi İslam Ansiklopedisi, C. 8, İstanbul 1993, s. 512-514.

ONUR, Bekir, Türkiye'de Çocukluğun Tarihi, İmge Kitabevi, Ankara 2005.

ÖZBEK, Nadir, "II. Abdülhamid ve Kimsesiz Çocuklar", Tarih ve Toplum, S. 182, Şubat 1999, s. $75-84$.

ÖZBEK, Nadir, Osmanlı Imparatorluğu'nda Sosyal Devlet-Siyaset, İktidar ve Meşruiyet 18761914, İletişim Yayınları, İstanbul 2011.

ÖZKAYA, Nevzad, Ehâsin-i Müessesât-1 Hayariyye-i Hilafetpenâhî’den Dârülaceze-Sultan II. Abdülhamid Han'ın Yaptırdığı Hayır Kurumlarından Darülaceze, Sadeleştiren: Mehmet Kanar, Aile ve Sosyal Politikalar Bakanlığı Dârülaceze Yayınları, İstanbul 2014.

ÖZTAN, Güven Gürkan, Türkiye'de Çocukluğun Politik İnşası, İstanbul Bilgi Üniversitesi Yayınları, İstanbul 2013.

SAĞLAM TEKİR, Hürü, "Osmanlı Devleti ve Kültür Coğrafyasında Sütannelik", Kafkas Üniversitesi Sosyal Bilimler Enstitüsü Dergisi, S. 24, 2019, s. 843-864.

ŞAFAK, Nurdan, “Osmanlı İmparatorluğu'nda Kimsesiz Çocuk Olmak ve Islahhaneler (18631903)”, Osmanlı Dünyasında Çocuk Olmak, İstanbul 2012, s. 131-163.

TEKİR, Süleyman, "Birinci Dünya Savaşı'nda Doğu Anadolu ve Doğu Karadeniz Rus İşgal Bölgelerinden Yapılan Göçler”, Çağdaş Türkiye Tarihi Araştırmaları Dergisi, 16/32, 2016 Bahar, s.43-64. 
TOKSÖZ, Hatice, “Osmanlı Klasik Dönem Ahlak Eserlerinde Çocuk eğitimi”, Osmanlı Dünyasında Çocuk Olmak, Değerler eğitimi Merkezi Yayınları, İstanbul 2012, s. 55-95.

ÜNLÜ, Mucize, "II. Abdülhamid Döneminde Balkanlarda Fakir ve Kimsesiz Çocuklar", Geçmişten Günümüze Şehir ve Çocuk II, Ed. Osman Köse, Canik Belediyesi Kültür Yayınları, Samsun 2016, s. 809-818.

YILDIRIM, Nuran, "Darülaceze'de Çocuk Bakımı ve Eğitimi-Lakita Dairesi ve Yetimhane, İmalathaneler, İlkokul", Toplumsal Tarih, 264, Aralık 2015, s. 26-35. , Istanbul Darülaceze Müessesesi Tarihi, Darülaceze Vakfı Yayınları, İstanbul 1996. , Nuran, Türkiye'nin İlk Kadın Doktoru Safiye Ali, Tarih Vakfı Yurt Yayınları, İstanbul 2012.

YILMAZ Demirci, Tuba, "Osmanlı ve Erken Cumhuriyet Dönemi Türkiye Modernleşmesinde Annelik Kurguları”, Cogito-Annelik, 81, Yaz 2015, s. 66-90. 